\title{
Key Success Factors' Identification of Farm Tourism: A Case from Indonesia
}

\author{
Indah Fatmawati ${ }^{1,}$, Sabila Ayu Bestari $^{2}$, and Rokhima Rostiani ${ }^{2}$ \\ ${ }^{1}$ Universitas Muhammadiyah Yogyakarta, Indonesia \\ ${ }^{2}$ Universitas Gadjah Mada, Indonesia
}

\begin{abstract}
The setting of this study is an orchard that has turned into thriving farm tourism. The company continues to develop itself in line with the high demand for horticultural products and tourism to excel in doing business. This research aims to identify the key success factors of a tourism farm company. Having useful information enables a company to understand its competitive advantages and powerful resources. Therefore, they can outperform the competition and prevent competitive losses. This study employs an exploratory qualitative approach. Data collection was using observation, interviews, and data generated from the company. This research is using three analytical techniques. First, the external environment analysis consisted of Political, Economic, Socio-Cultural, Technological, and Environmental analysis (PESTEL) and Porter's Five Forces Analysis (PFFA). Second, the internal environment analysis encompassed Value Chain analysis, STP analysis, and Marketing Mix analysis. Then, SWOT analysis to determine alternative strategies generated from the external and internal environment analysis. Results revealed that the key success factors of tourism farm company included human resources and natural resources. In this case, the company's service characteristic is inseparable. Lastly, the company must find solutions to overcome their weaknesses, such as the lack of technology and social media use.
\end{abstract}

\section{Introduction}

As a rural country with great potency for tourism, Indonesia earns benefits from its tropical region location [1]. One of its provinces that well known to be a tourism destination in Yogyakarta. In this province, Sleman has the most benefit due to the position of Mount Merapi. Yogyakarta has various attractions, such as historical/heritage tourism, culinary tourism, nature tourism, and farm tourism. Farm tourism is non-urban tourism conducted on a working farm where the tourist activity crisscrossed with the farm activity [2]. The functional farm part of farm tourism refers to the farming activity being practiced. The study setting is one of the local companies with global nuance located in Sleman, namely Sabila Farm. Established in 2005, Sabila Farm has been famous for its existence in the farm tourism industry. The primary farm production in Sabila Farm is organic/low pesticide dragon fruits. Sabila Farm has organized national and international exhibitions to promote organic/low

*Corresponding author: indahfatmawati@umy.ac.id 
pesticide horticulture productions and farm tourism as an established alternative to naturebased tourism. It has been won multiple awards for its contribution and dedication to agriculture.

Sabila Farm has the potential to continue to accelerate and achieve more success. Unfortunately, without understanding the key factors for its success, Sabila Farm is prone to make a wrong decision since they do not know which elements are essential. According to Thompson, a lack of understanding of the key success factors, competitive advantages, and driving forces within the industry can put companies at risk of failing moving forward [3]. According to Ceglinski there are two competitive advantage categories company can put their focus on [4]. The first is lower cost, it is for company who are willing enter the price war by offering lower price to attracts buyers. The second is differentiation, it is for company who will be unique as they can be to attract buyers by offering values other company fails to offer despite the price they set. Therefore, this research aims to help Sabila Farm identify its key success factors to create and execute competitive strategies to survive in the industry and become even more successful.

This research can contribute to Sabila Farm in analyzing the critical success factors already owned by Sabila Farm and improving its competitive advantages to become a better farm tourism destination. Other parties that benefited from this research are the government and other small horticulture farms. This research can be a case study on how to be successful in conducting farm tourism.

\section{Literature Review}

\subsection{Resource Advantage Theory}

This study's underlying idea is Resource Advantage Theory from Hunt and Morgan, which stated that a company's sound understanding of the internal and external resources would determine its success [5]. Understanding the critical success factor is essential as it is the company's source to develop their strategies. The critical success factor is the competitive factors that most influence a company's ability to survive and succeed in its business. It is part of strategy elements that separate the strong from the weak competitors from their profit and loss. The company needs to pay close attention to these factors to avoid the possibility of experiencing the risk of failure. Companies can design strategies to maximize their critical success factors in having a more robust industry position [3].

There are three questions to identify the company's critical success factors: (1) What resources and competitive capabilities a company must have to succeed in the competition? (2) What is the basis for customers to choose and purchase products than what competitors offer? What product attributes and service characteristics are critical to competitive success? (3) What are the weaknesses that can position the company in a significant competitive loss? By answering these three questions, companies can obtain information on their critical success factors.

\subsection{Concept and Variable Definitions}

\subsubsection{External Environment}

The external environment is all aspects surrounding the company, which the company has no direct control over. This analysis aims to find the company's possibility of earning more benefits and understanding which company's threats need to be avoided. Another objective 
is to find the key variables that offer possible responsive reactions [6]. One of the analysis techniques to analyze macro environment is by using PESTEL analysis [7]. This research's external analysis tools are PESTEL analysis and Porter's Five Forces [8].

\subsubsection{PESTEL Analysis}

PESTEL analysis is a strategic tool to help the analyst identify critical factors influencing a company's current situation by acknowledging, understanding, and making future decisions regarding the concepts, products, and business to be successfully executed. This analysis consists of Political Factors, Economic Conditions, Socio-Cultural Forces, Technological Factors, and Environmental Forces. It provides a framework to investigate the company's non-controllable external factors and consider these factors to minimize organizationalrelated risks and reach a better industry position [6].

\subsubsection{Porter's Five Forces}

The five forces model was a tool created by Michael Porter to perceive and explain how five fundamental competitive forces and their primary causes affect the industry by concedes the roots of an industry's ongoing profitability while providing a framework for forecasting and influencing competition time. In most industries, to decide what are the suitable business strategies, porter's five forces is one of the universally used models of determination [9]. This model is generally used as a tool to interpret and evaluate the industry where the company is in, as well as the competitive aspect of the company itself [10]. The porter's five forces model is set up on the viewpoint that a company's strategies should engage with the opportunities and threats in the external environment [11]. According to Porter on Harvard Business Review, understanding the industry framework is fundamental to effective strategic positioning [12]. Porter stated that the most vital forces are the most important in the strategy formulation for determining the industry's profitability among the competing parties [12]. Every company that competes in the industry must have its strategy. However, some strategic planning does not use analytical research that can cover all the company aspects. Therefore, the strategist needs to use this Five Forces analysis to understand the industry as a whole.

\subsubsection{Internal Environment}

The internal environment is all aspects of the company related to its competitive capability and internal resources. Usually, the company has full power over its internal situation and makes it one of its own decisions about where it will go. According to Fatmawati, one of the internal environment analytical tools is Value Chain Analysis [8]. The internal analysis was also covering analysis about Segmentation, Targeting and Positioning of the company, and Marketing Mix Analysis.

\subsubsection{Value Chain Analysis}

As proposed by Porter, value chain analysis is a tool to identify its competitiveness based on how it provides value to customers [12]. In term of tourism industry, the movement of the tourist from to the destination from their origin is the base of the value chain, which can be aided with the elements of the industry itself [13]. Value chain analysis identifies nine activities within a company. It consists of five primary activities and four secondary activities. 


\subsubsection{Segmenting, Targeting, and Positioning}

Companies must be able to understand their market to achieve success. According to Kotler and Keller, the market is an assemblage of buyers [14]. The industry is a compilation of sellers; the sellers hand over the goods or services, while the buyers hand out their money in return. The sellers cannot sell the same product or service to all customers because not every buyer has the same characteristics or abilities to purchase, affecting their likings and preferences. Therefore, they need to understand the market segmentation, target market, and position in the market. By recognizing these, sellers can provide better products or services that will cater to their needs, resulting in cost-efficiency and effective strategies. According to Ferrell and Hartline, segmentation helps the company to divide the entirety of market based on the products and services they offer into particular category [15].

\subsubsection{Marketing Mix}

A company must be able to master a series of marketing elements to achieve its goals. According to Kotler and Keller, a marketing mix is a marketing tool for the company to achieve its marketing objectives after developing its marketing STP strategy [14]. Alan Pomering et.al defined marketing as an activity that related with market, as a pursuit to form and present the organization's identity expectantly be able to perceive a positive image and marketplace can accept it [13]. In the tourism industry, marketing mix can assist the company to discover the demand and customer's interest of a destination [16]. There were numerous marketing elements that can be included for marketing mix, where only four filtered by McCarthy according to Pomering et al. that utilize in tangible marketing mix [17]. The elements are Product, Price, Place, and Promotion. Understood that the basic 4Ps marketing mix generally catered for product oriented business, Bitner in Pomering et al. later added 3Ps into the mix so it can be more usefull for business with product and service oriented, such as tourism [17]. The additional elements are People, Process, and Physical Evidence.

\subsubsection{SWOT Analysis}

In order to develop a strategy formulation, a company needs to analyze its strengths, weaknesses, opportunities, and threats by identifying its internal and external environment.

The company's strength is all of the company resources which are not owned by the competitor or the company's ability to perform particular activities better than the competitor. In contrast, a company's weakness is the unavailability of critical resources in the company owned by its competitor or its inability to perform particular activities to perform better. The opportunity identification in the company can be demonstrated by understanding the favorable circumstances that happen in the external environment, and the threat is the risk that must be faced by the company to excel. Referring to Fatmawati, this study performed a SWOT analysis by analyzing the external and internal environment [8]. The SWOT matrix is an analytical tool utilized to formulate strategies. This matrix can depict how opportunities and threats can be adapted with strengths and weaknesses and adjusted to the external environment and the internal environment [6]. This analysis method is needed to assess and appraise the company's strengths, weaknesses, opportunities, and threats in their business and activities [18]. SWOT analysis is a part in planning and developing a strategy, with the goal is to have a positive relationship between the internal and external environment [19]. 


\subsection{Research Framework}

Below is the framework to identify Sabila Farm's critical success. This study is using descriptive analysis. The analysis starts from the external investigation about the companies' industry and internal analysis of value chain analysis. The external examination consists of analyzing the environment's macro factors using PESTEL analysis and micro aspects of the ground using Porter's Five Forces analysis. The internal environment analysis is using value chain analysis, STP analysis, and marketing mix analysis. The external research found its opportunity and threat, while the internal investigation found its strengths and weaknesses. The next analysis process is SWOT analysis to identify the critical success factors of Sabila Farm.

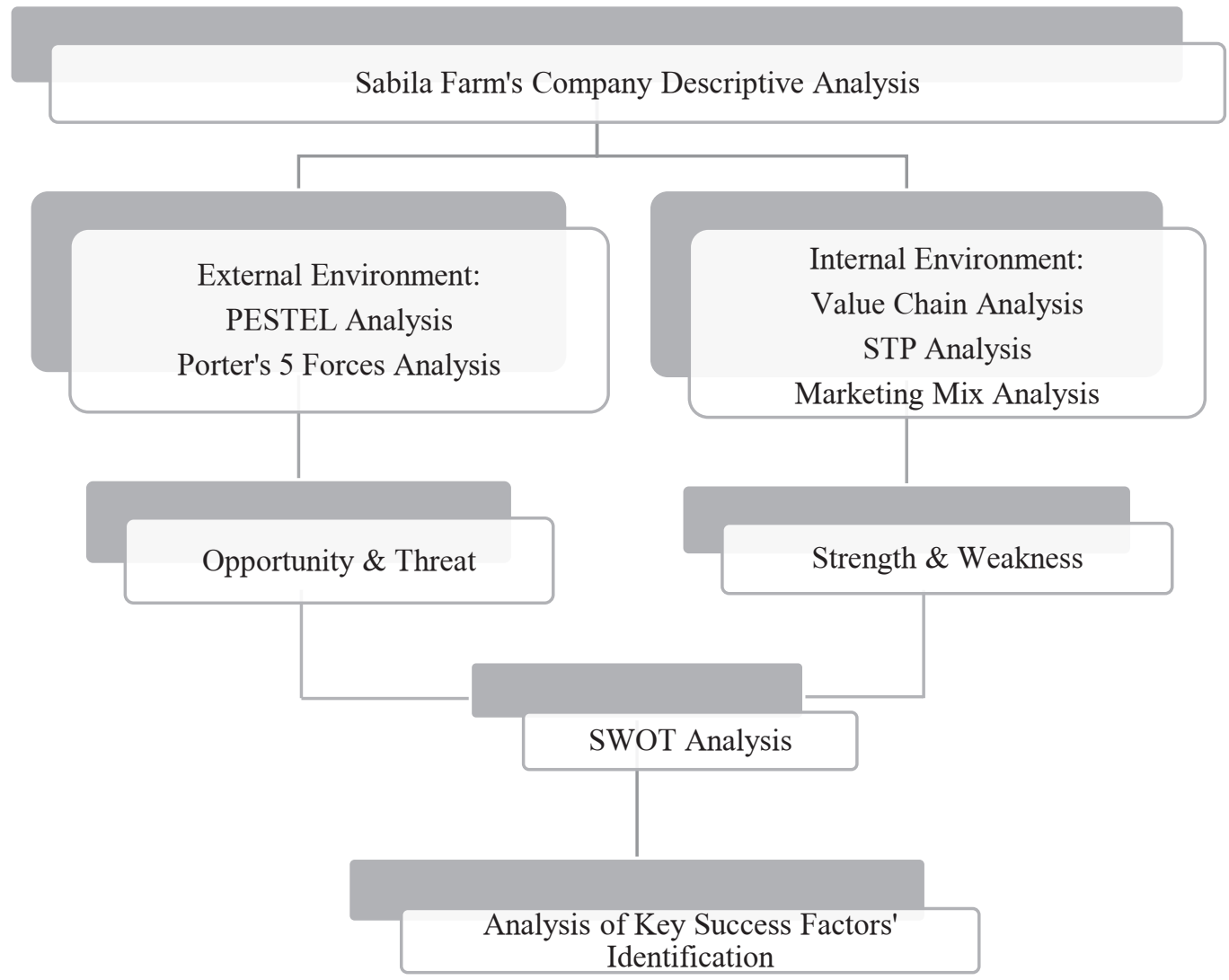

Fig. 1. The Research Framework to Identify Key Success Factor in Sabila Farm

\section{Research Method}

\subsection{Research Approach}

This research's approach is constructionism. This approach aims to understand people's mind by investigating it thoroughly. Constructionism highlights how people formulate insight and judgment from their proficiency based on the situation it took place. This approach is qualitative and more concerned with the particular case than the generality of the discovery and research result. An exploratory qualitative approach was employed in this research with 
Sabila Farm as the case study for exploration. Sekaran and Bougie stated that a case study tries to understand an organization's problem through an in-depth analysis, which can solve different organizations' dispute in a similar situation [20]. Rather than quantitative, a case study tends to yield qualitative analysis and interpretation.

\subsection{Research Informant}

This research's informant consisted of three categories. The first category was from the company's internal member, both Sabila Farm's owner and manager. Both of them have the expertise of knowledge and first-hand experience in dealing with the company's daily activities. The second category was from the company's buyers, both the event organizer and Sabila Farm buyers. These informants were selected based on their purchasing experience and repeated buying behavior towards the company's tourism package and organic/low pesticide fruits. The third category was a rival company named Kebon Naga, as the benchmark for this research. The owner of Kebon Naga's become our external member informant.

\subsection{Research Setting}

The research setting was Sabila Farm. The location of the company is in Pakem, Sleman, Yogyakarta. Depicted as an eminent fruit farming in Yogyakarta and throughout Indonesia, Sabila Farm is different from other farms that mainly only perform one activity. Sabila farm serves from carrying out production, education, and recreation simultaneously. Sabila Farm has run its business practices under the government's standard operating procedure by releasing its varieties for white and red dragon fruit. It was also certified by the Ministry of Agriculture and the Department of Agriculture in the Special Region of Yogyakarta as the farm with Good Agriculture Practices (GAP). Moreover, both owners and Sabila Farm, as the company, have won multiple awards for their dedication and devotion to Indonesian agriculture continuity.

\subsection{Sampling Method}

This study using non-probability sampling. The type of sampling design used in this research was judgment sampling. This sampling design aims to obtain more relevant information that can only be available to specific groups. According to Saunders, the requirement for in-depth interviews range from 5 to 25 sample size [21]. Agreed to this theory, Yin suggested that the norm of sample size should be 6 [22]. In this regard, from the company side, two informants are the owner and manager. Meanwhile, from the buyer side, six informants are the event organizer and repeated customers. Lastly, there was one as the benchmark from a rival company. Therefore, in total there will be nine informants, and this number is suitable for the qualitative research with in-depth interviews.

\subsection{Instrument Testing}

The instrument testing in this study is using a validity and reliability test. The validity test ensures that all of the indicators in the questionnaire measured the construct under investigation. While reliability tests ensuring that the measurements give consistent results among repeated measurements. Unlike quantitative analysis, this exploratory qualitative research used instrument quality tests based on a narrative manner. This test aims to prove that this research's findings are valid and reliable. Other researchers who seek to study a 
similar problem can learn from this research. In qualitative research, according to Lincoln and Guba in Korstjens and Moser, the term for the research's trustworthiness is defined into four criteria: credibility, transferability, dependability, and confirmability [23].

\subsection{Data Collection}

This research requires both primary and secondary data. The primary data are collected directly through interviews, and secondary data are from journals, articles, books, and previous research. This study garnered the primary data through direct interactions, where the researchers visited Sabila Farm multiple times for observation. The interviews with the manager and owners are using candid face-to-face interviews, and with the customers, it was through a phone call interview. The interview questions are referring to on a list of questions prepared beforehand. The type of item was open-ended, where the informants could answer as many as they could to gain more well-rounded information. This investigation obtained the secondary data through readings, both online and printed, including journals, research, and books.

\subsection{Data Analysis}

This research is using an exploratory qualitative approach. This method tried to answer external and internal information affecting the key success factors of Sabila Farm. All information obtained by the researchers provided a clear picture of the factors that could be the key success of Sabila Farm and gave conclusions and suggestions for its future references. In order to analyze all recorded information in qualitative research, this study used grounded theory. Grounded theory, founded by Glaser and Straus, is an emerging analysis where the analysis started with no data preconceptions [24]. This way, the researcher would go through data, then followed by defining codes and themes. For the coding system, the researchers utilized line-by-line coding. It is a code to summarize each line in the interviews' transcript. The researchers would assign each line into code to describe what the transcript line means. The primary data collection uses interviews, and the secondary data documentation uses information resources from the data provider, such as Central of Statistic Berau. After completing the data collection process, the next investigation step is analyzing the data to perform a SWOT analysis to conclude the key success factors of Sabila Farm.

\section{Result and Discussion}

\subsection{Company's General Condition}

Sabila Farm is an agribusiness of farm tourism, education, and organic/low pesticide tropical fruit production. Dragon Fruit is its primary and iconic fruit product. Sabila Farm has been registered its brand under intellectual property rights. Sabila Farm was established in 2005 by husband-wife Mr. Gunung Soetopo and Mrs. Elly Mulyati as a family business. There are two core principles of the Sabila Farm business. The first is to establish the farm on marginal land, and the second is to cultivate fruit products with beneficial values. By 2020, the total farm area is \pm 6 hectares, with \pm 4 hectares for farm production and \pm 2 hectares for farm tourism. Sabila Farm has helped twenty-five horticulture farms in Indonesia. Fourteen of them started with 'Sabi' (i.e., Sabisa, Sabita, Sabilo, etc.), assisting them to be distinctive from other similar farms as it is iconic and associated with Sabila Farm. 


\subsection{Instrument Testing Result}

\subsubsection{Credibility}

This research employed a prolonged engagement strategy. The researchers conducted a series of extended interviews to engage with the informants and gain enough information needed. The researchers prepared three sets of question guidelines for each informants' category as the interviews' preparation. This type of interview guidelines was open-ended questions, where the informants were allowed to answer as much as they thought they needed. The researchers prepared follow-up questions for the informants' answers.

\subsubsection{Transferability}

Transferability in this study refers to the instrument's ability to be implemented in different settings of farm companies. This research's objective is to identify the farm tourism company's critical success factors. Transferability of this research instrument to another setting is essential.

\subsubsection{Dependability}

To assure the informants' answers were similar to the researcher's understanding, the researchers asked them to reiterate their answers. The informants could ascertain whether the researchers had the same interpretation as their answer or not. If not, the informants were allowed to confirm it with the researchers.

\subsubsection{Confirmability}

In order to confirm the research findings, the researchers updated the data before conducted the research. Updating the data is to assure that the researchers had a neutral interpretation. Furthermore, to have an unbiased understanding of the company, the researchers performed a benchmark to a rivalry company by comparing the value chain carried out by Sabila Farm and the competitor.

\subsection{Discussion}

Discussion of the results is using a set of analysis tools. The data were gathered from three categories. The first was the Sabila Farm's representatives, the second was Sabila Farm's customers, and the third was Sabila Farm's competitor. The discussion is about the external and internal environment and SWOT analysis to conclude its crucial success factors.

\subsubsection{External Environment}

The external environment is one of the vital points of success factors. The analysis tools for external environment analysis were PESTEL analysis and Porter's 5 Forces analysis. 


\subsubsection{PESTEL Analysis}

Table 1. Summary of PESTEL Analysis

\begin{tabular}{|l|l|}
\hline \multicolumn{1}{|c|}{ Indicators } & \multicolumn{1}{c|}{ Analysis } \\
\hline Political Factors & $\begin{array}{l}\text { Law of the Republic of Indonesia Number 13 of 2010 concerning } \\
\text { Horticultural Agrotourism }\end{array}$ \\
\hline Economic Condition & $\begin{array}{l}\text { The economy of the Yogyakarta Special Region Province grew 5.26\% } \\
\text { in the fourth quarter of 2017. }\end{array}$ \\
\hline Socio-Cultural Forces & $\begin{array}{l}\text { Among other cities and regencies in the Special Region of Yogyakarta, } \\
\text { Sleman has the highest population, contributing to 31.39\% of the total } \\
\text { population in this province. }\end{array}$ \\
\hline Technological Factors & $\begin{array}{l}\text { Dragon Fruit plants cultivate manually throughout the phases, and the } \\
\text { farming characteristics also affected the tools used. }\end{array}$ \\
\hline Environmental Forces & $\begin{array}{l}\text { The location of Sabila Farm is only 14 kilometers away from the peak } \\
\text { of Mount Merapi. }\end{array}$ \\
\hline $\begin{array}{l}\text { Legal and Regulatory } \\
\text { Forces }\end{array}$ & $\begin{array}{l}\text { Regulation of the Minister of Agriculture of the Republic of Indonesia } \\
\text { Number 70/Permentan/PD.2006/6/2014 concerning Guidelines for } \\
\text { Horticultural Cultivation Business Permits }\end{array}$ \\
\hline
\end{tabular}

\subsection{Political Factor}

Law of the Republic of Indonesia, Number 13 of 2010 is concerning Horticultural Agrotourism. It states that agritourism is a horticulture business or regional development activity. It can be performed individually or in the broader tourist area and other tourist objects. The primary commodities are horticulture products [25].

\subsection{Economic Condition}

The economy of the Yogyakarta Special Region Province grew 5.26\% in the fourth quarter of 2017 compared to the fourth quarter of 2016, which was higher than the growth in the same period in 2016 of $4.78 \%$ [26]. This number of expansions implied a company's development and its customer's purchasing power.

\subsection{Socio-Cultural Forces}

Among other cities and regencies in the Special Region of Yogyakarta, Sleman has the highest population, contributing to $31.39 \%$ of this province's total population [27]. With the age range of 25 - 29 years, the young generation, both male and female, has the highest population number in the Special Region of Yogyakarta. The residents of Yogyakarta Special Region spent an average monthly expense for Household, Food, and Non-Food, mostly over $\mathrm{Rp} 1,000,000$ per category per person.

\subsection{Technological Factors}

Sabila Farm used limited essential technology tools to tillage and lawnmower for the front yard's grassy area. The process of other agricultural activities such as fertilizing and harvesting is still manual. Aside from the types of Dragon Fruit plants that have been done 
better manually throughout their phases, the farming characteristics also affected the tools used. Sabila Farm wants to promote simple farming so that many people are inspired to open the same business without heavily investing in technology tools.

\subsection{Environmental Forces}

The location of Sabila Farm is only 14 kilometers away from the peak of Mount Merapi, which is known as one of the most active volcanos in the world. The recent volcanic activity happened in May 2018, where there were phreatic eruptions. It raised the status of Waspada Level II (Alert Level II) by the National Board for Disaster Management [28].

\subsection{Legal and Regulatory Forces}

Regulation of the Minister of Agriculture of the Republic of Indonesia Number 70/Permentan/PD.2006/6/2014 concerns Guidelines for Horticultural Cultivation Business Permits. It states that the farm or business area registration number is the code for horticulture cultivation that has implemented Good Agriculture Practices and comply with the farm or business land registration requirements. Sabila Farm already fulfilled and owned legal entities, such as Good Agricultural Practices registration, fruit varieties registration, and derivative product registration.

\subsubsection{Porter's 5 Forces}

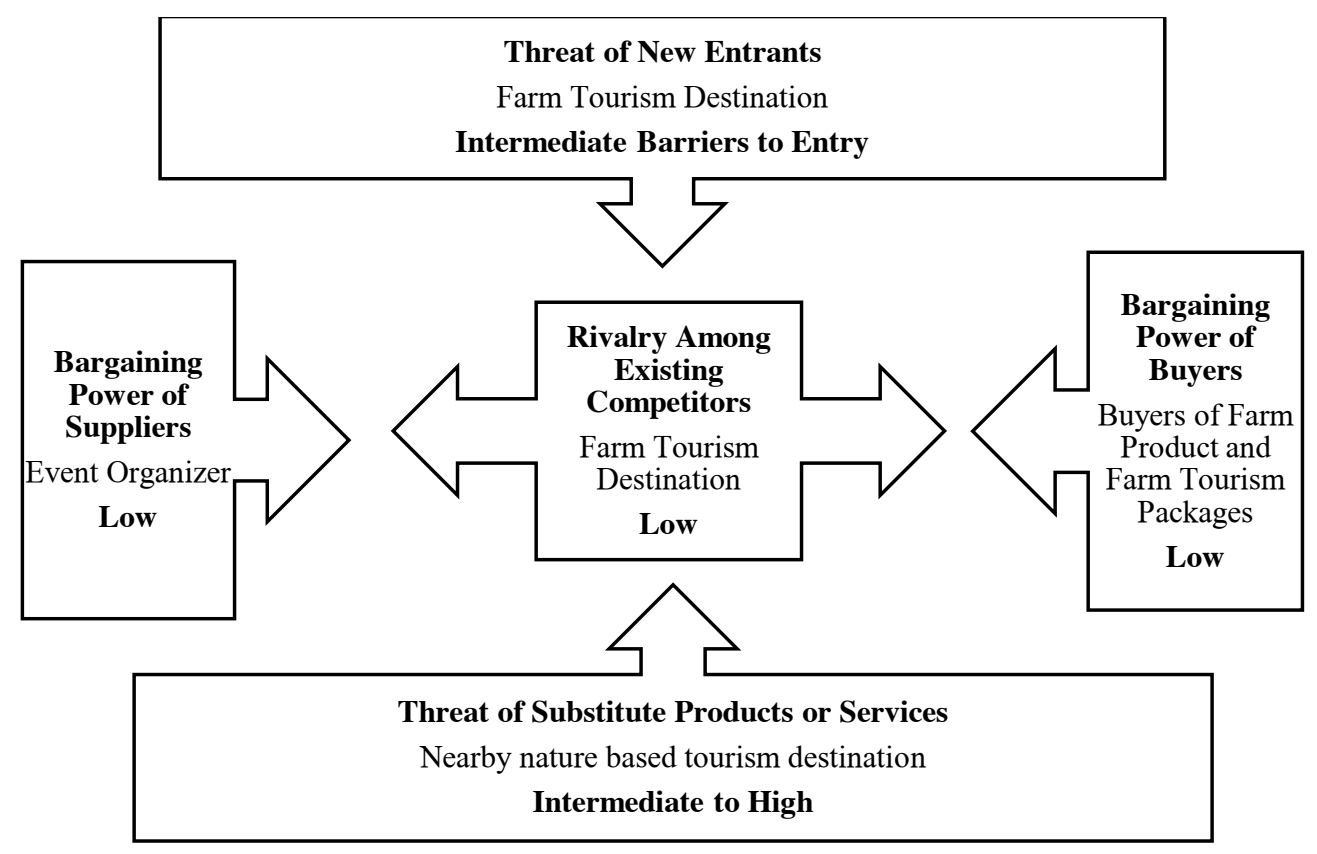

Fig. 2. Porter's Forces Analysis Tool 


\subsection{Suppliers' Bargaining Power}

Table 2. Suppliers' Bargaining Power

\begin{tabular}{|c|l|l|l|}
\hline No. & \multicolumn{1}{|c|}{ Indicators } & \multicolumn{1}{|c|}{ Analysis } & \multicolumn{1}{c|}{ Conclusion } \\
\hline 1 & $\begin{array}{l}\text { Number of } \\
\text { suppliers }\end{array}$ & $\begin{array}{l}\text { There are many event organizers and } \\
\text { travel agents. }\end{array}$ & $\begin{array}{l}\text { Suppliers' bargaining } \\
\text { power was low. }\end{array}$ \\
\hline 2 & $\begin{array}{l}\text { Raw materials } \\
\text { supplied }\end{array}$ & $\begin{array}{l}\text { There are many steering committees or } \\
\text { trip organizers for the community. }\end{array}$ & $\begin{array}{l}\text { Suppliers' bargaining } \\
\text { power was low. }\end{array}$ \\
\hline 3 & $\begin{array}{l}\text { Switching cost of } \\
\text { raw materials }\end{array}$ & $\begin{array}{l}\text { There is no cost for switching from one } \\
\text { supplier to another. }\end{array}$ & $\begin{array}{l}\text { Suppliers' bargaining } \\
\text { power was low. }\end{array}$ \\
\hline 4 & $\begin{array}{l}\text { Replacement } \\
\text { availability }\end{array}$ & $\begin{array}{l}\text { There are many replacements provided } \\
\text { by other suppliers. }\end{array}$ & $\begin{array}{l}\text { Suppliers' bargaining } \\
\text { power was low. }\end{array}$ \\
\hline \multicolumn{2}{|c|}{ Conclusion } & The bargaining power of the supplier towards Sabila Farm was low. \\
\hline
\end{tabular}

Sabila Farm's supplier, in terms of farm tourism, was the organizer who brought visitors to the farm. The organizers can come from a community or professional. From the community, usually, they are committees of a group of visitors. Sabila Farm did not give the event organizers any incentives, such as those earned from the participant payments. Sabila Farm gave them fruits, derivative products, or merchandise. Therefore, there was no switching cost from one event organizer to another. In terms of payment, event organizers were allowed to ask for a rounding amount and give a discount if they brought a large group. These travel agents and event organizers could only get rounding prices and good deals. They did not earn an additional fee from Sabila Farm. Therefore, the bargaining power of the supplier towards Sabila Farm was low.

\subsection{Buyers' Bargaining Power}

Table 3. Buyers' Bargaining Power

\begin{tabular}{|c|c|c|c|}
\hline No. & Indicators & Analysis & Conclusion \\
\hline 1 & Number of Buyers & Many buyers exist. & $\begin{array}{l}\text { Buyers' bargaining } \\
\text { power was low. }\end{array}$ \\
\hline 2 & Buying capacity & $\begin{array}{l}\text { As a result of coming as visitors, } \\
\text { they purchase farm products. }\end{array}$ & $\begin{array}{l}\text { Buyers' bargaining } \\
\text { power was low. }\end{array}$ \\
\hline 3 & $\begin{array}{l}\text { Information about prices } \\
\text { and quality of goods in } \\
\text { the market }\end{array}$ & $\begin{array}{l}\text { The buyer has the necessary } \\
\text { information about the product's } \\
\text { price. }\end{array}$ & $\begin{array}{l}\text { Buyers' bargaining } \\
\text { power was low. }\end{array}$ \\
\hline 4 & $\begin{array}{l}\text { Switching cost to other } \\
\text { providers/sellers }\end{array}$ & $\begin{array}{l}\text { Prices are competitive as many other } \\
\text { farm tourism companies offer } \\
\text { relatively similar starting price. }\end{array}$ & $\begin{array}{l}\text { Buyers' bargaining } \\
\text { power was } \\
\text { intermediate }\end{array}$ \\
\hline & Conclusion & \multicolumn{2}{|c|}{$\begin{array}{l}\text { The bargaining power of the buyers toward Sabila Farm was } \\
\text { low }\end{array}$} \\
\hline
\end{tabular}

Sabila Farm's customers were farm tourism visitors. They come in a group along with their business organizations, some were through event organizer (EO), and some were through their community. These EOs would book a visit to Sabila Farm and organize the whole trip. The switching cost to another farm tourism was low since they offered a similar price with Sabila Farm. The customer could only get a rounding price and reasonable discount for their purchase. Therefore, the bargaining power of buyers toward Sabila Farm was low. 


\subsection{Threat of Substitute Service}

Table 4. The Threat of Substitute Service

\begin{tabular}{|c|l|l|l|}
\hline No. & \multicolumn{1}{|c|}{ Indicators } & \multicolumn{1}{|c|}{ Analysis } & \multicolumn{1}{c|}{ Conclusion } \\
\hline 1 & $\begin{array}{l}\text { The Number of } \\
\text { Substitutes }\end{array}$ & $\begin{array}{l}\text { There are a few nature-based tourism destinations } \\
\text { nearby the farm. }\end{array}$ & $\begin{array}{l}\text { Substitute threat } \\
\text { was high }\end{array}$ \\
\hline 2 & Substitutes Price & $\begin{array}{l}\text { There are variations in substitute price, some are } \\
\text { cheaper, and some are higher. }\end{array}$ & $\begin{array}{l}\text { Substitute threat } \\
\text { was } \\
\text { intermediate }\end{array}$ \\
\hline 3 & $\begin{array}{l}\text { Substitutes } \\
\text { Performance }\end{array}$ & $\begin{array}{l}\text { Nature-based tourism destinations have good } \\
\text { performance. }\end{array}$ & $\begin{array}{l}\text { Substitute threat } \\
\text { was high }\end{array}$ \\
\hline 4 & Switching Cost & $\begin{array}{l}\text { a. The switching cost to another nature-based } \\
\text { tourism destination is relatively low. } \\
\text { b. The switching cost for a substitute is medium. }\end{array}$ & $\begin{array}{l}\text { Substitute threat } \\
\text { was } \\
\text { intermediate }\end{array}$ \\
\hline \multicolumn{2}{|c|}{ Conclusion } & The threat of substitutes was intermediate to high. \\
\hline
\end{tabular}

In agriculture, four subsectors are under the agriculture sector in Indonesia. Firstly, it is a food crop cultivation. It includes rice, corn, and roots. Secondly is plantation crops, including palm, coconut, cacao, rubber, and tea. Thirdly is animal husbandry; it is where two-legged and four-legged farmed animals. Finally is horticulture as the fourth, which includes fruit and vegetable. Sabila Farm is in the fourth one. As Yogyakarta's nature-based tourism industry is on the rise, many other substitutes providers of Sabila Fam. The nature-based tourism sites offered a similar starting price to Sabila Farm. Their performances were relatively good, in terms of the number of visitors. Therefore, the threat of substitutes was intermediate to high.

\subsection{Threat of New Entrants}

Table 5. The Threat of New Entrants Summary

\begin{tabular}{|c|l|l|l|}
\hline No. & \multicolumn{1}{|c|}{ Indicators } & \multicolumn{1}{|c|}{ Analysis } & \multicolumn{1}{c|}{ Conclusion } \\
\hline 1 & Customer's Loyalty & $\begin{array}{l}\text { The customers of Sabila Farm } \\
\text { are mostly loyal, as the number } \\
\text { of satisfactions is high. }\end{array}$ & $\begin{array}{l}\text { The barrier to entry } \\
\text { was high. }\end{array}$ \\
\hline 2 & Product Differentiation & $\begin{array}{l}\text { Sabila Farm offered many farm } \\
\text { tourism packages, in which the } \\
\text { package's activities are quite } \\
\text { different from other farm } \\
\text { tourism destinations. }\end{array}$ & $\begin{array}{l}\text { The barrier to entry } \\
\text { was high. }\end{array}$ \\
\hline 3 & Investment Cost & $\begin{array}{l}\text { Sabila farm needs to adjust the } \\
\text { cost of creating farm tourism } \\
\text { with the budget. }\end{array}$ & $\begin{array}{l}\text { The barrier to entry } \\
\text { was low. }\end{array}$ \\
\hline 5 & Switching Cost & $\begin{array}{l}\text { The entrance price depends on } \\
\text { the packages offered. }\end{array}$ & $\begin{array}{l}\text { The barrier to entry } \\
\text { was low. }\end{array}$ \\
\hline & $\begin{array}{l}\text { Access to Suppliers and } \\
\text { Distribution Channel }\end{array}$ & $\begin{array}{l}\text { Every farm tourism company } \\
\text { can have the same event } \\
\text { organizer, and a travel } \\
\text { organizer depends on their } \\
\text { preferences. }\end{array}$ & $\begin{array}{l}\text { The barrier to entry } \\
\text { was intermediate. }\end{array}$ \\
\hline \multicolumn{2}{|c|}{ Conclusion } & The barrier to entry was intermediate. \\
\hline
\end{tabular}

The new companies willing to invest in opening new nature-based tourism sites are always open. Since Yogyakarta is well known for its tourism, any kind of tourism sites will have a chance of success. The area near Sabila Farm is still full of natural scenery. Therefore, 
the opportunity to establish a new one is always desirable. According to the Yogyakarta Special Region Development Planning Agency, the number of nature-based tourism in 2020 was 32, almost double than in 2018 [29]. Although the number of new entrants is increasing, from the satisfaction level and willingness to revisits, the expected loyal customer of Sabila Farm was still high.

\subsection{Rivalry Amongst Existing Competitors}

Table 6. Rivalry Among Existing Competitors Summary

\begin{tabular}{|l|l|l|l|}
\hline No. & \multicolumn{1}{|c|}{ Indicators } & \multicolumn{1}{|c|}{ Analysis } & Conclusion \\
\hline 1 & Number of Rivals & $\begin{array}{l}\text { There is only one direct competitor with } \\
\text { Dragon Fruit farm tourism with a radius of 9 } \\
\text { km away. The other competitors are other } \\
\text { kinds of fruit farms. }\end{array}$ & $\begin{array}{l}\text { Rivalry power } \\
\text { was low. }\end{array}$ \\
\hline 2 & Industry Growth & $\begin{array}{l}\text { There is no Dragon Fruit farm nearby Sabila } \\
\text { Farm, but many new dragon farms are in other } \\
\text { places. }\end{array}$ & $\begin{array}{l}\text { Rivalry power } \\
\text { was low. }\end{array}$ \\
\hline 3 & $\begin{array}{l}\text { Product } \\
\text { Differentiation }\end{array}$ & $\begin{array}{l}\text { Sabila Farm offers many farm tourism } \\
\text { packages, in which the package's activities are } \\
\text { quite different from other farm tourism } \\
\text { destinations. }\end{array}$ & $\begin{array}{l}\text { Rivalry power } \\
\text { was low }\end{array}$ \\
\hline \multicolumn{2}{|c|}{ Conclusion } & The rivalry among existing competitors was low. \\
\hline
\end{tabular}

One of its direct competitors is Kebon Naga. Established in 2001, Kebon Naga has added a restaurant, café, and lodging to its business model from farm production and farm tourism to capture a broader market. The price offered started from $\mathrm{Rp} 100.000$ up to $\mathrm{Rp} 5.000 .000$ for the complete package, including farm tourism packages, workshops, meals, lodging, and seedlings. Kebon Naga allowed the farm to be a wedding venue. The total of visitors to Kebon Naga was around 50.000, up to 70.000 per year. It included the restaurant and café customers, wedding venue guests, farm tourism visitors, and lodging guests. Although they were competing, their target market was different. The target markets for Sabila Farm were mainly pre-retirement workers and university students. Meanwhile, in Kebon Naga, they were preschoolers and junior high school students. Therefore, the level of competition was low.

\subsubsection{Internal Environment}

The internal environment investigation's objective is to answer the second question regarding its vital success factor. The second question relates to why customers choose this company over other companies offering similar services and the company's main service characteristics. In the internal environment, the objective of Value Chain Analysis, STP analysis, and Marketing Mix analysis is to analyze the data from observation and interviews.

\subsubsection{Value Chain Analysis}

Value chain analysis is comparing a company's activities with its benchmark. There are two categories of activities in value chain analysis, i.e., supporting and primary activities. The benchmark is Kebon Naga Farm. 
Table 7. Value Chain Primary Activities of Sabila Farm

\begin{tabular}{|c|c|c|c|}
\hline Primary Activities & Example & $\begin{array}{l}\text { Sabila } \\
\text { Farm }\end{array}$ & $\begin{array}{c}\text { Kebon } \\
\text { Naga } \\
\end{array}$ \\
\hline \multirow{2}{*}{ Inbound Logistics } & Preparation & 9 & 7 \\
\hline & Visitors Arrival & 8 & 8 \\
\hline \multirow{2}{*}{ Operations } & Farm Tourism Activities & 10 & 7 \\
\hline & Tourism Packages & 9 & 7 \\
\hline Outbound Logistics & Visitors Departure & 10 & 7 \\
\hline \multirow{7}{*}{$\begin{array}{l}\text { Marketing } \\
\text { and Sales }\end{array}$} & Marketing Strategy & 9 & 6 \\
\hline & Distribution channel & 7 & 9 \\
\hline & Pricing & 9 & 7 \\
\hline & Advertising & 8 & 8 \\
\hline & Promotion & 9 & 8 \\
\hline & Sales & 8 & 9 \\
\hline & Order processing & 8 & 8 \\
\hline \multirow{4}{*}{ Service } & Customer support & 7 & 9 \\
\hline & Value for the customer & 9 & 8 \\
\hline & Maintenance & 7 & 9 \\
\hline & Data Administration & 10 & 6 \\
\hline \multicolumn{2}{|c|}{ Overall Score } & $\begin{array}{l}\text { Total }=137 \\
\text { Avg }=8,56\end{array}$ & $\begin{array}{c}\text { Total }=123 \\
\text { Avg }=7,69\end{array}$ \\
\hline \multicolumn{2}{|c|}{ Score Margin } & \multicolumn{2}{|c|}{0,87 point } \\
\hline
\end{tabular}

From the primary activities, Sabila Farm earned a higher point than Kebon Naga by 0,87 points. One interesting point is these two companies' operations. Sabila Farm's main focus was to integrate tourism with the farm activities; therefore, the score was still the farm itself. Meanwhile, for Kebon Naga, the farm was an additional attraction, and people could visit the farm to enjoy the company's complete amenities, such as a cafe, restaurant, and lodging. Therefore, the two companies had their focus, although they run a similar business.

Table 8. Value Chain Secondary Activities of Sabila Farm

\begin{tabular}{|c|c|c|c|}
\hline Secondary Activities & Example & Sabila Farm & Kebon Naga \\
\hline \multirow{4}{*}{ Firm Infrastructure } & Physical evidence & 8 & 9 \\
\cline { 2 - 4 } & Office equipment & 9 & 7 \\
\cline { 2 - 4 } & IT services & 6 & 9 \\
\cline { 2 - 4 } & Maintenance goods and services & 9 & 7 \\
\hline \multirow{2}{*}{$\begin{array}{c}\text { Muman Resources } \\
\text { Management }\end{array}$} & Recruiting & 9 & 6 \\
\cline { 2 - 4 } Technology & Training & 9 & 6 \\
\cline { 2 - 4 } Development & Product design & 9 & 6 \\
\hline \multirow{2}{*}{ Procurement } & Process design & 9 & 7 \\
\cline { 2 - 4 } & Supply procurement & 9 & Total $=72$ \\
& Material procurement & Total $=85$ & Avg=7,2 \\
\hline \multirow{2}{*}{ Overall Score } & \multicolumn{2}{|c}{1,3 point } \\
\hline
\end{tabular}

From the secondary activities, Sabila Farm earned a higher score than Kebon Naga by 1,3 points. One interesting fact was that the Human Resource Management category. In Sabila Farm, there was a designated division to take care of farm tourism activities, and it had a tour guide and instructor. The owner always involves in the activities. Meanwhile, in Kebon Naga, there was no specific division or staff for the farm tourism activities. The owner himself performs all of the activities with four-person assistants. 


\subsubsection{Segmentation, targeting, and positioning analysis}

The second analysis tool to answer the second question on the company's critical success factors was STP analysis. This analysis is about the company's market. The analysis emphasized on company's market segments, target market, and market position.

\subsection{Segmentation}

Table 9. Market Segmentation for Sabila Farm

\begin{tabular}{|l|l|}
\hline \multicolumn{1}{|c|}{ Indicator } & \multicolumn{1}{c|}{ Service } \\
\hline Geographic & $\begin{array}{l}\text { a. The domestic visitor, it is from all over Indonesia, mainly Java island. } \\
\text { b. For foreign visitors, it is from all over the world, mainly neighboring } \\
\text { countries and Europe. }\end{array}$ \\
\hline Demographic & $\begin{array}{l}\text { a. Age: Adult (23-60 years old) and Young Adult (18-22 years old) } \\
\text { b. Education: Well-educated } \\
\text { c. Occupation: pre-retirement and students } \\
\text { d. Income: Middle to high-income earner }\end{array}$ \\
\hline Psychographic & $\begin{array}{l}\text { Based on price } \\
\text { a. Pricier: Motivation class, Intensive course } \\
\text { b. Less expensive: Farm Tour, in-class education, cooking class }\end{array}$ \\
\hline Behavior & $\begin{array}{l}\text { a. Benefits } \\
\text { b. Occasions }\end{array}$ \\
\hline
\end{tabular}

For farm tourism, Sabila Farm's market segmentation was various and had various backgrounds. The domestic market could come from all over Indonesia. Since it is located in Yogyakarta province with proper infrastructure from the city center to reach its location, there was no limitation to the visitors' geographic background. The farm tourism in Sabila Farm had no age limitation since the packages were suitable for all ages. Especially for mature visitors such as pre-retirement workers who wanted to open a similar business, they could come and see how to build the farm. The visitors did not just come for pictures, but there was educational value in each tourism packages offered by Sabila Farm. Therefore, it was also suitable for students from all ranges of educational stages.

\subsection{Targeting}

Table 10. Target Market of Sabila Farm

\begin{tabular}{|c|c|l|}
\hline Category & Strategy & \multicolumn{1}{c|}{ Implementation } \\
\hline Service & $\begin{array}{c}\text { Market } \\
\text { Specialization }\end{array}$ & $\begin{array}{l}\text { The target market is well educated middle-high income } \\
\text { earners interested in horticulture cultivation and its by- } \\
\text { product process through educational recreation. Therefore, } \\
\text { they gain benefits by understanding the business concept as } \\
\text { a whole. }\end{array}$ \\
\hline
\end{tabular}

For farm tourism packages, the target market was the people with good education under the complexity of organic/low pesticide farming while serving tourism activities and educating the buyers. They could absorb the inspiration given by Sabila Farm to motivate them to do something for themselves and be beneficial for the community. Although some of the farm tourism packages were relatively affordable for any segment, some of them were somewhat pricey and only sensible for buyers who understood the value that they earned for their money. 


\subsection{Positioning}

Table 11. Positioning for Sabila Farm

\begin{tabular}{|c|l|}
\hline Indicator & \multicolumn{1}{c|}{ Service } \\
\hline Category & $\begin{array}{l}\text { In educational recreation on a horticulture farm, customers can learn } \\
\text { and relax. }\end{array}$ \\
\hline Benefit & $\begin{array}{l}\text { With an affordable price, visitors can learn about the farm as a whole } \\
\text { through the packages. }\end{array}$ \\
\hline Problem Solving & $\begin{array}{l}\text { Other nature-based tourist destinations have an excellent array of } \\
\text { attractions, but they lack catering to the customer's needs. }\end{array}$ \\
\hline
\end{tabular}

The problem with some nature-based tourism sites was that the visitors only paid for the entrance fee and take pictures. There was no added value given to them. What differentiates Sabila Farm from other nature-based tourism was the added value that could be enjoyed by all ages. Sabila Farm's ability to provide farm tour packages coupled with the educational value could help the visitors know more about the farm, the environment, and all farm activities.

Table 12. Point of Parity and Point of Differences in Farm Tourism

\begin{tabular}{|c|c|c|}
\hline & Sabila Farm & Kebon Naga \\
\hline 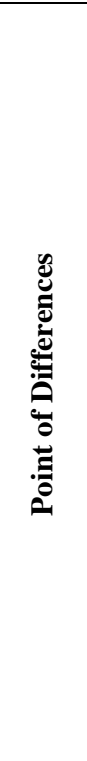 & $\begin{array}{l}\text { 1. Dragon Fruit is the farm icon. The farm } \\
\text { has } 11 \text { variations of fruit commodities in } \\
\text { total. } \\
\text { 2. Merapi Mountain can be directly seen } \\
\text { from the farm and can be a unique photo } \\
\text { background. } \\
\text { 3. It is located in the village residential area } \\
\text { and not on the street side, making the } \\
\text { ambiance calm and relaxing. } \\
\text { 4. It is located } 300 \text { meters away from the } \\
\text { main street in Yogyakarta, namely } \\
\text { Kaliurang street. } \\
\text { 5. Various tourism packages are offered, } \\
\text { accompanied by a tour guide and } \\
\text { instructor. } \\
\text { 6. All tourism packages have educational } \\
\text { value. } \\
\text { 7. Price is different, ranging from student, } \\
\text { worker, and foreigner. The price starts } \\
\text { from Rp } 15.000 \text { up to Rp } 75.000 \text { per } \\
\text { person. }\end{array}$ & $\begin{array}{l}\text { 1. Dragon Fruit is the farm icon and the only } \\
\text { commodity. } \\
\text { 2. The company does not have the Merapi } \\
\text { volcano view, and the photo background is } \\
\text { the plant itself. } \\
\text { 3. It is located directly on the street side, } \\
\text { which is strategically accessible by big } \\
\text { vehicles. } \\
\text { 4. It is located right on the side of the main } \\
\text { street in Yogyakarta, namely Kaliurang } \\
\text { street. } \\
\text { 5. Tourism packages depend on customer } \\
\text { request. } \\
\text { 6. The farm tour has educational value. } \\
\text { 7. The price range starts from Rp } 100.000 \text { up } \\
\text { to Rp } 4.000 .000 \text {. }\end{array}$ \\
\hline 芦 & $\begin{array}{l}\text { 1. Exciting and various farm commodities } \\
\text { 2. Scenic view of nature } \\
\text { 3. Tranquil ambiance }\end{array}$ & $\begin{array}{l}\text { 4. Strategic location } \\
\text { 5. Tourism activities/packages } \\
\text { 6. Have educational value } \\
\text { 7. Well priced }\end{array}$ \\
\hline
\end{tabular}

Similarities analysis resulted in seven points of similarities between Sabila Farm and its potential competitor Kebon Naga Farm. While for the differences between Sabila Farm and Kebon Naga, the tourism activities and the price profoundly differed. Since both companies captured roughly different markets, they did not fiercely compete despite having the same business model.

The external slogan of Sabila Farm was in Bahasa Indonesia, "Tekad, Semangat, Nekad!" The use of this slogan has been since the early year of the company was established. The 
meaning of the motto is when a person has willpower (tekads), that person must keep the spirit (semangat) and eventually just do it (nekad). Meanwhile, the internal mantra is "farming with a heart." The first part of the mantra is translated as farming with heart. The second part is translated as serving with the whole heart. The company wholeheartedly served its customers and care for them, starting from pick-up them from the parking area to deliver them back to their vehicle again.

Meanwhile, for Kebon Naga, what the researcher could translate from the brand's spirit was "Agrowisata Segala Ada," which translated into 'Holistic Agritourism.' The company provided as many amenities as possible for the customers, starting from the farm itself and the farm tourism they offered. With all facilities and services provided, it suits the brand mantra.

\subsubsection{Marketing Mix}

Table 13. Summary of Marketing Mix Analysis

\begin{tabular}{|c|c|c|}
\hline Category & Indicator & Analysis \\
\hline \multirow{4}{*}{ Product } & Attraction & $\begin{array}{l}\text { The tourism attraction is the farm itself and the packages } \\
\text { offered, which why people visit. }\end{array}$ \\
\hline & Accessibility & $\begin{array}{l}\text { It is easy to access through a digital map. There are an } \\
\text { international and wide range of domestic flights in Adi } \\
\text { Sucipto Airport and a wide range of domestic trips at seven } \\
\text { train stations in the Special Region of Yogyakarta. }\end{array}$ \\
\hline & Amenity & $\begin{array}{l}\text { There is various lodging near the farm with multiple price } \\
\text { ranges. }\end{array}$ \\
\hline & Ancillary & Limited parking space \\
\hline \multirow{5}{*}{ Place } & Channel Type & $\begin{array}{l}\text { Both the zero stage (direct) and one stage (indirect) } \\
\text { marketing channels are applied. }\end{array}$ \\
\hline & Coverage & $\begin{array}{l}\text { For farm tourism, } 96 \% \text { market is for domestic tourists (from } \\
31 \text { provinces) and } 4 \% \text { for international tourists (from } 31 \\
\text { countries). In the domestic market, } 29.4 \% \text { comes from } \\
\text { Yogyakarta Province. }\end{array}$ \\
\hline & Intermediaries & Partnership with travel agents or event organizer \\
\hline & Location & $\begin{array}{l}\text { The location is } n \text { the main street in Yogyakarta, and the road } \\
\text { is well built. }\end{array}$ \\
\hline & Transportation & $\begin{array}{l}\text { All transportation modes can reach the farm, but the big } \\
\text { travel bus cannot park inside the farm. }\end{array}$ \\
\hline \multirow{5}{*}{ Price } & Flexibility & $\begin{array}{l}\text { During the off harvest season, the cost of tour packages is } \\
\text { slightly reduced to compensate for the plants' absence of } \\
\text { fruits. }\end{array}$ \\
\hline & Price Level & $\begin{array}{l}\text { The price listed is relatively appropriate for the customer's } \\
\text { ability to purchase and profit from the farm. }\end{array}$ \\
\hline & Payment Period & $\begin{array}{l}\text { Customer can make their payment in two batches: down } \\
\text { payment and final payment. }\end{array}$ \\
\hline & Differentiation & $\begin{array}{l}\text { The price must be suitable for the customer for their income, } \\
\text { spending habits, and willingness to purchase. Sabila } \\
\text { provides sensible prices for Sabila Farm customers. } \\
\text { Compared with companies nearby with a similar business } \\
\text { model, Sabila Farm is still in the relatively cheap price } \\
\text { position. }\end{array}$ \\
\hline & Discounts & $\begin{array}{l}\text { There is no fee for tourism packages for agents, organizers, } \\
\text { and caretakers but not for meals and souvenirs. }\end{array}$ \\
\hline Promotion & Promotion Blend & $\begin{array}{l}\text { Direct Marketing: Face-to-face interaction during events, } \\
\text { using the brochure as the media }\end{array}$ \\
\hline
\end{tabular}




\begin{tabular}{|c|c|c|}
\hline & & $\begin{array}{l}\text { Exhibition: Using exhibition o farm production as a } \\
\text { promotion for farm tourism. } \\
\text { Packaging: Sabila Farm has packaging based on Sabila } \\
\text { Farm products' needs. } \\
\text { Point-of-sale Merchandising: Seminar Kit and souvenir are } \\
\text { the Farm's merchandise. }\end{array}$ \\
\hline & Salespeople & $\begin{array}{l}\text { The marketing staff will inform regular customers about the } \\
\text { farm's current condition, making them put interest and lead } \\
\text { to purchase. }\end{array}$ \\
\hline & $\begin{array}{l}\text { Internet (Web } \\
\text { Strategy) }\end{array}$ & $\begin{array}{l}\text { Sabila Farm has made a personal website for a long time and } \\
\text { has utilized social media. }\end{array}$ \\
\hline \multirow{5}{*}{ People } & Owner & $\begin{array}{l}\text { The owners are hospitable, educative, humble, and have an } \\
\text { essential role in Sabila Farm. They can be a good } \\
\text { representative of the farm. }\end{array}$ \\
\hline & Employees & $\begin{array}{l}\text { The employees are responsible, patient, and have adequate } \\
\text { knowledge about Sabila Farm. }\end{array}$ \\
\hline & Customers & The customers felt happy, secured, and honored. \\
\hline & Satisfaction & $\begin{array}{l}97,64 \% \text { of visitors were satisfied and very satisfied, and } \\
\text { only } 2,36 \% \text { were neutral, dissatisfied, and very dissatisfied. }\end{array}$ \\
\hline & $\begin{array}{c}\text { Willingness to } \\
\text { Repeat }\end{array}$ & $\begin{array}{l}\text { All visitors combined, } 66,31 \% \text {, were willing to revisit the } \\
\text { farm. }\end{array}$ \\
\hline \multirow{4}{*}{ Process } & Procedure & $\begin{array}{l}\text { The booking process is mainly via WhatsApp and phone } \\
\text { calls, and the event organizer can have an initial visit to } \\
\text { survey the place. }\end{array}$ \\
\hline & Mechanization & $\begin{array}{l}\text { Tour guide and instructor do their job of serving the visitors, } \\
\text { and the owner will be present to welcome and as the key } \\
\text { speaker on several classes, such as motivation and cooking } \\
\text { class. }\end{array}$ \\
\hline & Flow of Activity & $\begin{array}{l}\text { The farm tourism packages offering is using an } \\
\text { appointment. Therefore, it resulted in better planning of } \\
\text { tourism activities from the arrival, the tourism activities, and } \\
\text { departure. }\end{array}$ \\
\hline & $\begin{array}{l}\text { Customer } \\
\text { Involvement }\end{array}$ & $\begin{array}{l}\text { Visitors are allowed to ask questions throughout the whole } \\
\text { time of the visit. Cooking class and let's plant packages offer } \\
\text { hands-on involvement from the visitors. }\end{array}$ \\
\hline \multirow{4}{*}{$\begin{array}{l}\text { Physical } \\
\text { Evidence }\end{array}$} & Environment & $\begin{array}{l}\text { The scenery of Merapi Mountain creates a relaxing } \\
\text { ambiance for the visitor. }\end{array}$ \\
\hline & Signs & $\begin{array}{l}\text { The signboard on the side of Kaliurang's main street makes } \\
\text { the farm less visible to the general public. }\end{array}$ \\
\hline & Symbols & $\begin{array}{l}\text { Since the beginning of its operation, Sabila Farm has never } \\
\text { changed its logo. }\end{array}$ \\
\hline & Artifacts & $\begin{array}{l}\text { The Javanese style of Limasan house is unique and suitable } \\
\text { for the farm. }\end{array}$ \\
\hline
\end{tabular}

\subsection{Product}

Sabila Farm had the dedication to cater to each reservation based on the interest of the customer group. Their target market strategy, market specialization, allowed them to customize the materials to be delivered based on demands. The package's name would remain the same for each group, but the tour guide or instructor would only provide their material with the customer's needs. Hence, the customers would be able to absorb the information on the level with their capability. 
Table 14. Farm Tourism Packages in Sabila Farm

\begin{tabular}{|c|l|}
\hline Package Name & \multicolumn{1}{c|}{ Description } \\
\hline Farm Tour & $\begin{array}{l}\text { A tour guide accompanies the tour around the farm. It explains the } \\
\text { plants, how to plant, how to take care, how to harvest, and how to } \\
\text { do upkeep treatment. }\end{array}$ \\
\hline In- Class Education & $\begin{array}{l}\text { Participants will briefly get the necessary information and Sabila } \\
\text { Farm history to be inspired to create a similar business in their } \\
\text { interest. }\end{array}$ \\
\hline Motivation & $\begin{array}{l}\text { The motivation class is given by the owner and founder of Sabila } \\
\text { Farm, Mr. Gunung Soetopo, sharing his experiences in starting the } \\
\text { Sabila Farm business and pioneering it until it is now thriving. }\end{array}$ \\
\hline Cooking Class & $\begin{array}{l}\text { The participant will be taught by a cooking instructor, making } \\
\text { essential and easy-to-cooked dishes made from fruits available on } \\
\text { the farm. }\end{array}$ \\
\hline Intensive Course & $\begin{array}{l}\text { This package is specifically for participants who want to open an } \\
\text { agricultural business from the beginning to the end process. }\end{array}$ \\
\hline
\end{tabular}

Among many tour packages offered by Sabila Farm, the top five are on the table above. The most package taken from the farm's internal data was Farm Tour, followed by In-Class Education and Motivation class [30]. The natural attraction was the existence of Merapi Mountain that could be seen clearly on sunny days. Visitors sought any proper tourism location to get a nice photo with the mountain in the background and enjoyed its beauty. Its attraction was the plants that grew on the farm and the information/education delivered during the package's activities.

\subsection{Place}

The place is better than the location of competitors. It also includes the distribution channel of the company. It applies both zero stage and one stage channel of distribution. The one thing that might differ Sabila Farm from other nearby tourism sites was the entrance ticket on their arrival, and visitors had to book their visit beforehand. With the zero-stage supply chain, Sabila Farm offered the farm tourism packages to a general customer. They would be the steering committee and invited their communities or families to visit the farm. The onestage through intermediaries was the travel agent or event organizer who booked their visit. The travel agent and event organizer accommodated the visitors to come and enjoy the tourism package.

In terms of coverage, most of the domestic customers of Sabila Farm from the group and individual categories were from the Special Region of Yogyakarta province for 25,79\% [30]. In total, visitors from 31 areas out of 34 in Indonesia had visited the farm. Sabila Farm had attracted visitors in a large domestic market with the coverage of more than $90 \%$ of provinces in Indonesia. International visitors of Sabila Farm were coming from 31 countries. Due to the relationship with universities, such as Gadjah Mada University, most visitors were from Austria, resulting in the number of countries visiting Sabila Farm to vary significantly.

\subsection{Price}

Price is the amount of money given by customers to Sabila Farm for the product and services they earned. The company determined the price based on the quality of work and services. Understanding their customers' ability to purchase will help to determine the price they can afford. Sabila Farm gave the price based on the customer's ability to purchase. There are three 
categories of prices, two for domestic customers, consisting of student and working and preretirement, and one for foreign customers. The company gathered exciting data based on the guest book filled by customers who filled out the guest book. The customer's ability to spend on tourism expenditure includes the money they spend on travel, including accommodation, travel tickets, and entrance tickets to the tourism site monthly. Most customers were wellearned people with an income of more than $\mathrm{Rp} \mathrm{9.000.000} \mathrm{and} \mathrm{willing} \mathrm{to} \mathrm{spend} \mathrm{on} \mathrm{tourism}$ expenditure monthly for more than $\mathrm{Rp} 900.000$. Meanwhile, in contrast, the second most were people who earned less than Rp 1.500.000, and most of them were willing to spend less than Rp 150.000 for monthly tourism expenditure [30].

\subsection{Promotion}

Promotion is a way for a company to inform the market about its existence, its general description, and its product and service offered and served. Sabila Farm still employed the traditional marketing form of word-of-mouth. They believed in letting their product and service speaks for the company. Customers who had purchased and visited the farm and satisfied with their purchase and visit would share the stories with their family and friends, influencing them to come to the farm and order and make a reservation.

In-line with the marketing strategy, they used word-of-mouth based on their internal data. Most visitors knew Sabila Farm initially from their friends, 38,67\% [30]. The second place was the event organizer, travel agent, arranger, and steering committee informing the visitors. As for social media and websites, it is in the following place.

\subsection{People}

The term of people not only focuses on the employees but also on the owners who start the company. This term also refers to customers who purchase and enjoy the company's products and services. This way, people's analysis can be holistic from service providers and service recipients.

The owners' role is vital. They spend their time nurturing both the farm and employees and meeting with each customer as much as possible. The basic of Sabila Farm's existence was the owners' long-term project for their retirement, and since they had retired, they were willing to spend as much time as they could with any farm activities. Besides, Sabila Farm employees were people who graduated from university with an agricultural educational background. The owners learn hospitability aspects of farm tourism from the experience they served the customers for years. By having adequate knowledge about agriculture, these employees could give accurate information to the visitors.

In terms of customer satisfaction, according to the internal data of Sabila Farm, more than half of the visitors were very satisfied with their visit by $54,11 \%$ and satisfied by $43,53 \%$, which a total of $97,64 \%$ of visitors were pleased and delighted [30]. Only $2.36 \%$ of total visitors were neutral, dissatisfied, and very dissatisfied with their visit. Sabila Farm should be glad that the customers they tried to satisfy best were pleasant, and it was worth their hard work to please them.

For the willingness to revisit, the highest number of visitors was their first visit, and most of them stated that they were willing to come again and visit the farm. The second most was their second visit, and the majority of them indicated that they were ready to revisit. Sabila Farm's loyal customers have even visited the farm more than three times, and most would revisit. In total, around $66,31 \%$ of total visitors who filled the guest book stated that they were willing to revisit, and only $0.97 \%$ said they were not coming back again. 


\subsection{Process}

A process is vital for the service industry, including in farm tourism. The term process covers all activities in the tour package offered by Sabila Farm. It determined how well the customers perceived the product as it delivered by the company. The procedure of farm tourism activities in Sabila Farm had been set to coordinated by the people in charge. The tour guide was responsible for the farm tour activity by introducing plants on the farm and answering all visitors' questions. The instructor was responsible for in-class education, to deliver a presentation about the desired material, and answer all visitors' questions.

\subsection{Physical Evidence}

Physical evidence refers to the company's infrastructure. The infrastructure condition supported the activities of farm tourism. Located on the slope of Merapi Mountain and the middle of residency, the environment of Sabila Farm is tranquil. Therefore, it is a suitable escape place for urban people to get away from city life. The existence of Merapi Mountain has been a blessing from Sabila Farm. It gives the farm a unique scenery as the mountain is a part of the farm itself. With this view, the ambiance on the farm is appeared to be relaxing. A majestic background spoiled visitors for their photos. Since the farm location was not directly on the street side, Sabila Farm had to give a street sign to create an awareness of the farm. Unfortunately, the farm did not have a prominent street sign and spacious parking space for large vehicles, such as buses. Although, when people searched for Sabila Farm online, they could easily find it using Google Maps.

\subsubsection{SWOT Analysis}

Strength Opportunities (SO) Strategy:

S1O3. With most customers having high purchasing power, Sabila Farm should create specific tourism packages, where the packages' completeness and convenience are the keys. The price consideration is not a prominent aspect since they can afford it.

S3O5. All informants agreed that the owner played an essential role in choosing Sabila Farm as their destination, and the owner also became a good representation of the farm. With this information, Sabila Farm has created a package that allows the customer to engage with the owner.

Weakness Opportunity (WO) Strategies:

W2O2. With the number of social media users increasing every year, Sabila Farm must join the trend to stay relevant to the customers and attract more customers. The social media content can be about farm activities and the farm's current condition.

Strength Threat (ST) strategies:

S1T3. Sabila Farm must keep updating itself to stay relevant with the current trend. The benchmarks are the famous and new nature-based tourism sites that offer packages different, fresh, and unique than Sabila Farm offered.

Weakness Threat (WT) strategies:

W3T4. More visitors mean more vehicles parked on the farm. If Sabila Farm expects more visitors to come, they need to enlarge the parking space to match visitors' numbers. 
Table 15. SWOT Analysis

\begin{tabular}{|c|c|c|}
\hline & 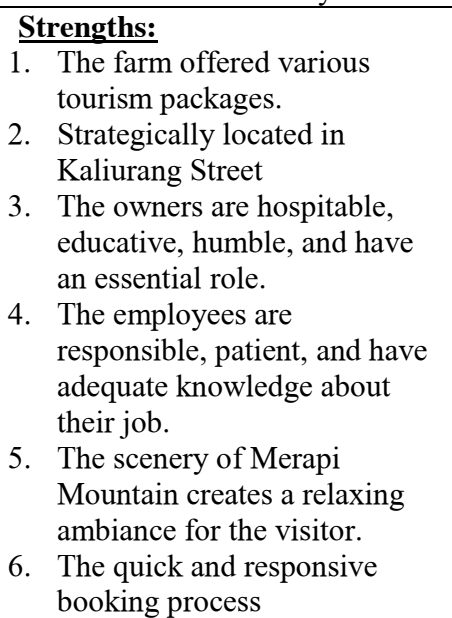 & $\begin{array}{l}\text { Weaknesses: } \\
\text { 1. Lack of technology } \\
\text { use } \\
\text { 2. Lack of social } \\
\text { media use as } \\
\text { promotion tools } \\
\text { 3. Limited parking } \\
\text { space }\end{array}$ \\
\hline 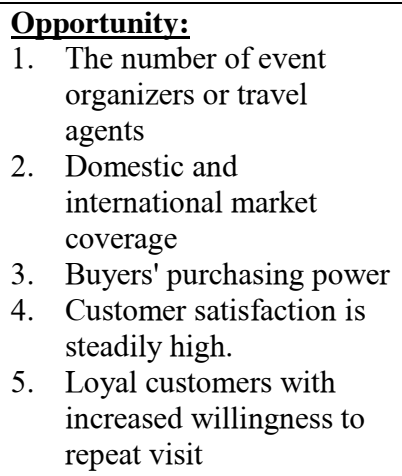 & $\begin{array}{l}\text { Strengths Opportunities } \\
\text { Strategies: } \\
\text { S1O3. Creating more premium } \\
\text { tourism packages to suit } \\
\text { the visitor's purchasing } \\
\text { power } \\
\text { S3O5.Creating more packages to } \\
\text { increase visitor's } \\
\text { engagement with the } \\
\text { owner }\end{array}$ & $\begin{array}{l}\text { Weaknesses } \\
\text { Opportunities } \\
\text { Strategies: } \\
\text { W2O2. Utilizing social } \\
\text { media as a tool } \\
\text { to engage with } \\
\text { customers in } \\
\text { the domestic } \\
\text { and } \\
\text { international } \\
\text { market }\end{array}$ \\
\hline $\begin{array}{ll}\text { Threats: } \\
\text { 1. } & \text { Eruption risk of Merapi } \\
\text { Mountain volcanic } \\
\text { activity } \\
\text { 2. Switching cost to other } \\
\text { nature-based tourism } \\
\text { sites } \\
\text { 3. The number of new } \\
\text { entrants in nature-based } \\
\text { tourism sites continues to } \\
\text { increase. } \\
\text { 4. } \begin{array}{l}\text { Good competitor's } \\
\text { performance }\end{array} \\
\end{array}$ & $\begin{array}{l}\text { Strengths Threats Strategies: } \\
\text { S1T3. } \\
\text { Creating up-to-date } \\
\text { tourism packages to } \\
\text { compete with more } \\
\text { modern nature-based } \\
\text { tourism sites }\end{array}$ & $\begin{array}{l}\text { Weaknesses Threats } \\
\text { Strategies: } \\
\text { W3T4. Providing large } \\
\text { parking space } \\
\text { and improving } \\
\text { facilities to } \\
\text { compete with } \\
\text { competitors }\end{array}$ \\
\hline
\end{tabular}

\subsubsection{Key Success Factors}

According to Thompson et.al, three questions can understand a company's critical success factors [3]: (1) What resources and competitive capabilities a company must have to be successful in the competition? (2) What is the basis for customers to choose and purchase products than what competitors offer? What product attributes and service characteristics are critical to competitive success? (3) What are the weaknesses that can position the company in a significant competitive loss? If Sabila Farm can answer these questions, they can be more empowered in their competitive advantages than their competitors in the industry. 
For the first question, there were two primary resources and competitive capabilities owned by Sabila Farm. The first resource was its human resources. All farm personnel, including the owners, tour guide, instructor, staff, and even laborers, were capable of their task. The second resource is natural resources. According to PESTEL analysis, the environmental forces of Sabila Farm are prone to Merapi Mountain eruption; on the right side is the view of nature that can be seen directly from the farm.

Sabila Farm owned two capabilities that could differentiate it from the competitors in terms of its competitive capabilities. The first competitive capability in terms of a tangible asset was intellectual property rights. Sabila Farm has registered its company name under HaKI. Twenty-five farms were being helped and guided by Sabila Farm, and fourteen of them have the word 'Sabi' in the front part of their name. It could distinguish the farms from other similar farms. It is also related to strong brand capabilities. The second competitive capability in terms of an intangible asset was the organizational culture. The ownership of the company itself was a family business. The way the company worked was based on the value of family and less rigid office characteristics. The people who worked on the farm were united to help each other despite their tasks.

For the second question, some factors influenced customers to purchase Sabila Farm's product. The first factor was the strategic location in Yogyakarta's main and vital streets, namely Kaliurang Street. This street close to Merapi Mountain, and visitors can directly see Merapi mountain from Sabila Farm. The second factor was the tourism packages. In Sabila Farm, the main product or the attraction was more than just a view for photo background but more on to educative tourism, where the visitors could learn how to take care of plants. The variations of tour packages offered by Sabila Farm were not limited to agriculture education and other life-skill, such as making derivative products out of fresh fruit directly taken from the farm. Motivation class and intensive course were two of the tourism packages related to entrepreneurship, and it could raise the visitors' entrepreneurial spirit. The third factor was that visitors could directly meet with the owners through interactive packages such as motivation classes that would inspire them to establish a similar business. According to the marketing mix analysis, all informants agreed that owners' involvement in Sabila Farm induced them to come to the farm. They felt honored and welcomed by the presence of owners. For the second part of the second question, the leading service characteristics of Sabila Farm was the inseparability of the providers' service. Since the farm charged a fee for tourism packages and not for the entrance fee, the farm's visit will rely on the farm personnel who provided information and education.

For the last question, based on the SWOT analysis, there were weaknesses and threats of Sabila Farm. Firstly, from the threat aspect, Merapi Mountain's high volcanic activity can be erupting at any time. It is an increased risk for the business. Therefore, Sabila Farm must be fully aware and prepare to alert the eruption and have proper safety protocols to evacuate. Furthermore, the number of new nature-based tourism has increased throughout the year, and they offered a similar price range. Sabila Farm must compete by providing more up-to-date tourism packages with various price ranges depending on the target market's capability. Since there is only one business that served the same product, which is a dragon fruit farm, Sabila Farm must be aware of the rival's performance. The competitor of Sabila Farm can provide complete amenities and large parking space. Therefore, to compete with them, Sabila Farm must be able to improve their facilities. Secondly, Sabila Farm's lack of social media and technology usage could create a barrier for the younger generation to come to the farm for the weakness aspect. Online presence is vital to stay relevant in the digital era. Social media can be the platform for promotion and the platform to educate more people about farm tourism. Another weakness is that Sabila Farm only had limited parking space since its location is in the middle of the residency area. With such limited parking space, many visitors choose the other farm tourism over Sabila Farm. 


\section{Conclusion, Limitation, and Suggestion}

\subsection{Conclusion}

This research aimed to identify the critical success factors of farm tourism, with Sabila Farm as the case study. This research's informants were Sabila Farm's owner and manager, the buyers, including the event organizers and visitors, and the direct competitor. The method of collecting data were observation and interviews, both face-to-face and via telephone. This research's results are as follows:

1. The critical success factors of Sabila Farm concerning the primary resources are the human resources and natural resources. The main competitive advantage is differentiation, and the main competitive capabilities are intellectual property and organizational culture.

2. The critical success factors of the Sabila farm regarding the customers' reasons for choosing Sabila Farm are the strategic location, the educative tourism packages, and the owner. The main service characteristics are the inseparability of the service from the farm personnel.

3. The suggestions for Sabila Farm regarding the threats are the Merapi Mountain eruption prevention, the increasing new nature-based tourism sites with the low switching cost, and the competitor's good performance. The company's weaknesses are the lack of technology and social media use and the lack of parking space.

\subsection{Limitation}

This research's main limitation is that only one competitor is used as a direct benchmark for this research. The more companies used as a benchmark may produce a more accurate mapping of their position in the market and better results.

\subsection{Suggestions}

Based on this research's limitation, the suggestion for future research is to have more companies as the subject of investigation. It can make future research have more insight into the factors influencing a company's success. Companies from various agriculture subsectors can enrich the research results. Many farm tourism destinations from other agricultural subsectors, such as food crops, plantations, and animal husbandry, can be investigated to improve the research value. Hopefully, future researchers can fill the gap of this limitation and increase the generalizability of critical success factors in all kinds of farm tourism.

\section{References}

1. S.N. Utami, B.H. Purwanto, D. Marwasta, The Effect of Merapi Volcano Eruption on Land Use Change and Agriculture, Agrotech Research Journal, vol. 6, no. 1 pp. 1-16 (2020)

2. S. Philip, C. Hunter, K. Blackstock, A Typology for Defining Agritourism, Tourism Management, vol. 31, issue 6 pp. 754-758 (2010)

3. A.A Thompson, M.A. Peteraf, J.E. Gamble, A.J. Strickland, Crafting \& Executing Strategy: The Quest For Competitive Advantage, 20th edition (McGraw-Hill, New York, 2016) 
4. P. Cegliński, The Concept of Competitive Advantages. Logic, Sources and Durability, Journal of Positive Management, vol. 7, pp. 57-70 (2017)

5. R. Morgan, S.D. Hunt, The Resource-Advantage Theory of Competition: A Review, Review of Marketing Research, vol. 1, pp. 153-206 (2010)

6. F. David, D.R. Forest, Strategic Management: A Competitive Advantage Approach, 15th edition (Prentice Hall, New Jersey, 2015)

7. S. Ulubeyli, O. Kazanc1, A. Kazaz, V. Arslan, Strategic Factors Affecting Green Building Industry, Sakarya University Journal of Science, vol. 23, issue 6 pp. 1042-1055 (2019)

8. I. Fatmawati, Manajemen Strategik (LP3M UMY, Yogyakarta, 2018)

9. S. Jaradat, S. Almomani, M. Bataineh, The Impact of Porter Model's Five Competence Powers on Selecting Business Strategy: An Empirical Study on Jordanian Food Industrial Companies, Interdisciplinary Journal of Contemporary Research in Business, vol. 5, no. 3 pp. 457-470 (2013)

10. G. Evans, C. Neu, The Use of Strategic Forces to Understand Competitive Advantages Provided by Information Technology, Journal of International Technology and Information Management, vol. 17, issue 2 (2008)

11. G. Bruijl, The Relevance of Porter's Five Forces in Today's Innovative and Changing Business Environment, SSRN Electronic Journal, pp. 1-21 (2018)

12. M. Porter, The Five Competitive Forces That Shape Strategy, Harvard Business Review (2008)

13. A. Pomering, G. Noble, L.W. Johnson, Conceptualising a Contemporary Marketing Mix for Sustainable Tourism, Journal of Sustainable Tourism, vol. 19, issue 8 pp. 953-969 (2011)

14. P. Kotler, K.L. Keller, Marketing Management, 14th edition (Prentice Hall, New Jersey, 2012)

15. O. Ferrell, M. Hartline, Marketing Strategy, 5th edition (South-Western Cengage Learning, Boston, 2011)

16. R. Singh, Marketing Mix for Sustainable Tourism, International Journal of Management Research and Review, vol. 4, issue 8 pp. 825-829 (2014)

17. A. Pomering, L. Johnson, G. Noble, Sustainable Tourism Marketing: What Should be in The Mix? Proceedings of the Australian and New Zealand Marketing Academy Conference pp. 1-8 (2009)

18. E. Gürel, M. Tat, SWOT Analysis: A Theoretical Review, The Journal of International Social Research, vol. 10, issue 51 pp. 994-1006 (2017)

19. D. Oresk, Strategy Development by Using SWOT-AHP, TEM Journal, vol. 1, no. 4 pp. 283-391 (2012)

20. U. Sekaran, R. Bougie, Research Methods for Business, A Skill Building Approach, 6th edition (John Wiley \& Sons Ltd, New Jersey, 2013)

21. M.N.K. Saunders, G. Symon, C. Cassel, The Practice of Qualitative Organizational Research, pp. 37-55 (SAGE Publications, London, 2012)

22. R.K. Yin, Case Study Research Design and Methods, 5th edition (SAGE Publications, California, 2014)

23. I. Korstjens, A. Moser, Series: Practical Guidence to Qualitative Research. Part 4: Trustworthiness and Publishing, European Journal of General Practice, vol. 24, no. 1 pp. $120-124$ (2018) 
24. B.G. Glaser, A.L. Strauss, The Discovery of Grounded Theory: Strategies For Qualitative Research (Routledge, New York, 2017)

25. Direktorat Pengembangan Usaha dan Investasi Kementerian Pertanian, Pedoman Umum Agrowisata (Kementerian Pertanian Republik Indonesia, Jakarta, 2012)

26. Bank Indonesia Daerah Istimewa Yogyakarta, Laporan Perkembangan Perekonomian DIY Triwulan IV Tahun 2017 (2018)

27. Badan Pusat Statistik Provinsi D.I. Yogyakarta, Proyeksi Penduduk Menurut Kelompok Umur dan Jenis Kelamin di D.I. Yogyakarta (2017)

28. Badan Nasional Penanggulangan Bencana, Status Gunung Merapi Dinaikkan Waspada Level II, Radius 3 KM Dikosongkan (2018)

29. Bappeda Daerah Istimewa Yogyakarta, Aplikasi Dataku Daerah Istimewa Yogyakarta (2020)

30. Sabila Farm, Laporan Tahunan Sabila Farm: 2019 (2019) 